\title{
Generation of Thematic Maps of a Forest Watershed using Remote Sensing and GIS
}

\author{
K.M. Gojiya ${ }^{1}$ *, N.K. Gontia ${ }^{2}$ and K.C. Patel ${ }^{1}$ \\ ${ }^{1}$ Department of Soil and Water Conservation Engineering, College of Agricultural \\ Engineering and Technology, Junagadh Agricultural University, Gujarat, 362001, India \\ ${ }^{2}$ College of Agricultural Engineering and Technology, Junagadh Agricultural University, \\ Junagadh, Gujarat, 362001, India
}

*Corresponding author

\begin{tabular}{|c|c|}
\hline & I B S T R A C T \\
\hline Keywords & \multirow{3}{*}{$\begin{array}{l}\text { The study was carried out to develop various thematic maps for a restricted forest } \\
\text { watershed named Machhundri, located at Gir Sanctuary of Saurashtra region in Gujarat, } \\
\text { India. Different thematic maps comprising of elevation map, aspect map, contour map, } \\
\text { land use/land cover map, slope map, drainage map and soil map were generated using } \\
\text { remote sensing and GIS methods. Satellite imageries and ArcGIS software were used in } \\
\text { the process. Steeper slopes with denser contour lines were found in upstream areas of the } \\
\text { catchment while relatively flat area with moderately spaced contours was discovered in } \\
\text { downstream. The area was found to be undisturbed as being inside a reserved forest. Major } \\
\text { percentage of watershed area ( } 96 \text { percent) was having loamy soil texture and almost } 98 \\
\text { percent area was under forest land cover class which may well be the reason of lesser } \\
\text { erosion and low peaks of runoff. Watershed was found to be sixth order catchment with } \\
\text { steeper slopes found near first order stream. }\end{array}$} \\
\hline Article Info & \\
\hline & \\
\hline
\end{tabular}

\section{Introduction}

Remote sensing methods have been established as tools to generate data on spatial and temporal basis, providing it in digital form with high resolution in preference to point measurement data. The utilization of remote sensing technology encompasses spatial information of large extent therefore involves an efficient system for handling such data. Geographical information system (GIS) can store, exhibit, recover and dissect the spatial data in agreeable approach. GIS has been widely used in many studies for spatial and temporal data creation. These spatial and temporal data generation through RS and GIS can help in various further studies including input for hydrological models and these could be extremely significant variables specifically in situation where on field data collection is tricky.

Thematic maps are comprised of traditional content features such as geographic features, 
mathematical features and secondary and supplementary elements (Kovarik and Talhofer, 2013). Mathematical elements represent a design basis of a map and they include projection, map scale, grids, map frame, etc. Geographic elements describe geographic features of the landscape, such as land use, elevation, topography, soil etc. and auxiliary and supplementary elements contains items such as composition elements, map lettering, etc. A thematic map displays spatial spreading of particular data themes for the specific geographic area, which could be further useful and in most cases could be used in further comprehensive studies. Thematic maps can be combined for generating combination maps with more information, which helps in researches like land suitability studies, hydrologic modelling, etc. Thematic maps are often used as a fundamental input in numerous hydrologic studies using compound modeling practises. Previous work (Paul et al., 2008) shows that thematic maps can be used to develop water and land resource management plans. In that study, thematic maps such as land use/land cover map, geomorphology map, soil map, slope map, drainage map were developed using satellite imageries and survey of India topo sheet. In another study, thematic maps of Malegaon watershed in Nasik district were generated (Suryawanshi and Bhutada, 2010). Base maps like drainage network, watershed boundary and contour maps were prepared using the satellite data and topographic map. Srinivas et al., 2007 prepared contour map, drainage map, soil map, morphology map, slope map and land use/land cover map using Survey of India toposheets and satellite images. A few different investigations have likewise been directed on different angles, which incorporate development of thematic maps or usage of the equivalent in different works (Murthy et al., 2000).Digital elevation model (DEM), slope map, soil map, aspect map, land use/land cover map and contour map were developed in this study using remote sensing and GIS techniques.

\section{Materials and Methods}

\section{Study area}

This study was performed on a forest river watershed named Machhundri located in Gir Sanctuary, Gujarat, India. Watershed area is between $20^{\circ} 57^{\prime} \mathrm{N}$ to $21^{\circ} 11^{\prime} \mathrm{N}$ latitudes and $70^{\circ} 50^{\prime} \mathrm{E}$ to $71^{\circ} 00^{\prime} \mathrm{E}$ longitudes as shown in Figure 1. The climate of the area inclines to have hot, occasionally extremely hot summers and warm to cool winters, according to Koppen-Geiger system (Peelet al., 2007). Area gets around $1100 \mathrm{~mm}$ of annual average rainfall. Catchment area is not accessible without permit of local forest department as whole area falls inside Gir National Park. This makes any data observations harder, where RS and GIS approach is very useful.

\section{Digital Elevation Model (DEM)}

DEM of the study area was created utilizing remotely sensed imagery called Digital Elevation Model (DEM) file of $30 \times 30$ resolution. DEM characterizes the topography of the region by portraying the elevation of any point at any specific location. The original DEM file was acquired from Bhuvan portal of National Remote Sensing Centre, which is initially generated using IRS Satellite Cartosat-1 images. For using the DEM as input for other map preparation, it was initially projected to study area location as Universal Transverse Mercator (UTM) zone 42. DEM was clipped for the study area extent using of Geo processing tool of ArcGIS software.

\section{Slope map}

Slope of the terrain can be perceived from the percent slope map. It is one of the most essential maps for any land or water 
management studies. Percentage slope map was prepared using DEM file for the study area. Figure 2 illustrates how the slope map was generated step by step in ArcGIS software. The slope map was prepared with different slope ranges, which were classified according to land capability classification (Tejwani, 1976).

\section{Aspect map}

Aspect portrays the direction of slope facing and relates to the solar exposure of the surface. Steps followed in generation of the surface aspect map in ArcMap 10.2 software are shown in Figure 2. Earlier prepared DEM file was used as input for generating aspect map of the study region.

\section{Contour map}

Contour map displays the imaginary lines having same elevations called contour lines. A contour map is very useful in knowing nature of the terrain.DEM file was used to generate the contour map for the study area. A comprehensive contour map having normal as well as index contour lines was prepared. Steps followed in ArcMap 10.2 software for generation of contour map are shown in Figure 2.

\section{Land use/land cover map and soil map}

Bhaskaracharya Institute for Space Applications and Geoinformatics (BISAG), Gandhinagar provided land use/land cover map and soil map were used for the generation of study area LULC map and soil map respectively. LULC map obtained from BISAG was originally prepared using LISS-III sensor images of Resourcesat-1 satellite. Soil map prepared by National Bureau of Soil Survey \& Land Use Planning (NBSS \& LUP), was obtained from BISAG, Gandhinagar; was used as input for preparation of study area soil map. Cross verification by ground truth inspections were also considered for preparing land use/land cover map.

\section{Drainage map}

DEM file was used to prepare drainage map of the study region. Firstly 'Fill' function in 'Hydrology' tools of ArcMap 10.2 was used to make depression less DEM file. If DEM file isn't depression less, flow-direction file prepared would be erroneous. Input of depression less DEM was used to prepare flow direction file, by using 'Flow Direction 'function in 'Hydrology' tools. Flow direction tool makes a raster of stream course from every cell to its downslope neighbor. Flow accumulation file was then prepared using flow direction as an input, which calculates accumulated flow in every downslope cells. Flow accumulation and flow direction together were used as input in 'Stream Order' function. The stream ordering can be done in ArcMap using Stream Order function of Spatial Analyst Hydrology tool. Although the Stream Order tool lacks on accuracy as it calculates each intersecting drains as individual streams, following that the stream ordering was done manually as well by using the Editor tool of ArcMap. Flowchart showing procedure to prepare drainage map can be seen in Figure 3.

\section{Results and Discussion}

Various thematic maps such as elevation map, slope map, aspect map, contour map, soil map, drainage and stream order map and land use/land cover map using remotely sensed imagery were prepared using ArcMap 10.2 GIS software. All the maps were generated on 1:200000scale.

\section{Digital elevation model}

In the study area, elevation ranged from minimum $46 \mathrm{~m}$ from MSL to maximum $431 \mathrm{~m}$ from MSL. Major percentage of area (86 percent) fell below $230 \mathrm{~m}$ MSL while only about 2 percent area of upstream end was above $330 \mathrm{~m}$ MSL elevation. The DEM of the study area is shown in Figure 4. 


\section{Slope map}

The slope map was generated using DEM file. Percent area in all respective slope classes are shown in Table 1. Study area terrain was having maximum 78 percent slope. Analysis of the slope map showed that 3.09 and 12.39 percent area was under $0-1$ and 1 3 percent slope range respectively. 3-10 and 10-25 percent slope range accounted for 36.54 and 33.41 percent of watershed area respectively. Whereas 13.94 and 0.62 percent of area had fallen under 25-50 and 5078 percent slope range category. The slope map generated for the study area is shown in Figure 5. Steeper slopes were found in upstream areas of the catchment.

\section{Aspect map}

The aspect map of watershed was generated using DEM file. Aspect categories are symbolized using different colors in Figure 6. In the prepared map, total 9 directions are shown based on degree, namely north $\left(337.5^{\circ}\right.$ to $\left.22.5^{\circ}\right)$, northeast $\left(22.5^{\circ}\right.$ to $\left.67.5^{\circ}\right)$, east $\left(67.5^{\circ}\right.$ to $\left.112.5^{\circ}\right)$, southeast $\left(112.5^{\circ}\right.$ to $\left.157.5^{\circ}\right)$, south $\left(157.5^{\circ}\right.$ to $\left.202.5^{\circ}\right)$, southwest $\left(202.5^{\circ}\right.$ to $247.5^{\circ}$ ), west $\left(247.5^{\circ}\right.$ to $\left.292.5^{\circ}\right)$, northwest $\left(292.5^{\circ}\right.$ to $\left.337.5^{\circ}\right)$ and including flat terrain as well. The map analysis showed that 0.98 , $11.02,10.07,11.41,13.36,16.03,14.14,12.02$ and 10.96 percent area of the watershed fell under flat, north, northeast, east, southeast, south, southwest, west and northwest directions respectively.

\section{Contour map}

The contour map of watershed was generated using DEM file. The contour map generated is shown in Figure 7. Normal contours are spaced at $20 \mathrm{~m}$ vertical interval while in index contour lines are spaced at $60 \mathrm{~m}$ vertical interval and shadier in colour and denoted by their respective elevations in the map. Contour lines can be seen denser in upstream end of the Machhundri catchment, while in remaining area contours are moderately spaced which favours in steepness in upstream end.

\section{Land use/land cover map}

The watershed was classified into six dominant land use/land cover categories viz. fair forest, poor forest, wastelands, agriculture, built-up and water bodies as can be seen from Figure 8 . The GIS analysis of the land use showed that $89.47,8.46,1.34,0.45,0.27$ and 0.01 percent area of the watershed were under fair forest, poor forest, water bodies, wastelands, agriculture and built-up respectively. Fair and poor forest classes combined accounts for almost 98 percent which shows the dominant land cover of forest in the study area.

Table.1 Area under different slope classes

\begin{tabular}{|c|c|c|c|}
\hline Sr. No. & Slope class & Area (ha) & Area(percent) \\
\hline 1 & 0 to 1 & 648.72 & 3.09 \\
\hline 2 & 1 to 3 & 2598.05 & 12.39 \\
\hline 3 & 3 to 10 & 7660.37 & 36.54 \\
\hline 4 & 10 to 25 & 7004.55 & 33.41 \\
\hline 5 & 25 to 50 & 2922.64 & 13.94 \\
\hline 6 & 50 to 78 & 130.51 & 0.62 \\
\hline \multicolumn{2}{|c|}{ Total } & 20964.84 & 100.00 \\
\hline
\end{tabular}


Table.2 Area under different land use/land cover classes

\begin{tabular}{|cccc|}
\hline Sr. No. & Land use class & Area (ha) & Area (percent) \\
\hline $\mathbf{1}$ & Fair Forest & 18756.61 & 89.47 \\
\hline $\mathbf{2}$ & Poor Forest & 1772.83 & 8.46 \\
\hline $\mathbf{3}$ & Water bodies & 279.88 & 1.34 \\
\hline $\mathbf{4}$ & Wastelands & 95.37 & 0.45 \\
\hline $\mathbf{5}$ & Agriculture & 57.03 & 0.27 \\
\hline $\mathbf{6}$ & Built-up & 3.12 & 0.01 \\
\hline & Total & 20964.84 & 100 \\
\hline
\end{tabular}

Table.3 Area under different soil classes

\begin{tabular}{|ccc|ccc|}
\hline $\begin{array}{c}\text { Sr. } \\
\text { No. }\end{array}$ & Texture & Area (ha) & $\begin{array}{c}\text { Area } \\
\text { (percent) }\end{array}$ & Description & Order \\
\hline $\mathbf{1}$ & Loamy & 20120.10 & 95.97 & $\begin{array}{c}\text { Loamy, Mixed, Hyperthermic, } \\
\text { Calcareous, Lithic Ustorthents }\end{array}$ & Entisols \\
\hline $\mathbf{2}$ & Fine & 844.74 & 4.03 & $\begin{array}{c}\text { Fine, Mixed, Hyperthermic, } \\
\text { Calcareous, VerticUstochrepts }\end{array}$ & Inceptisols \\
\hline & Total & 20964.84 & 100 & & \\
\hline
\end{tabular}

Fig.1 Study area location
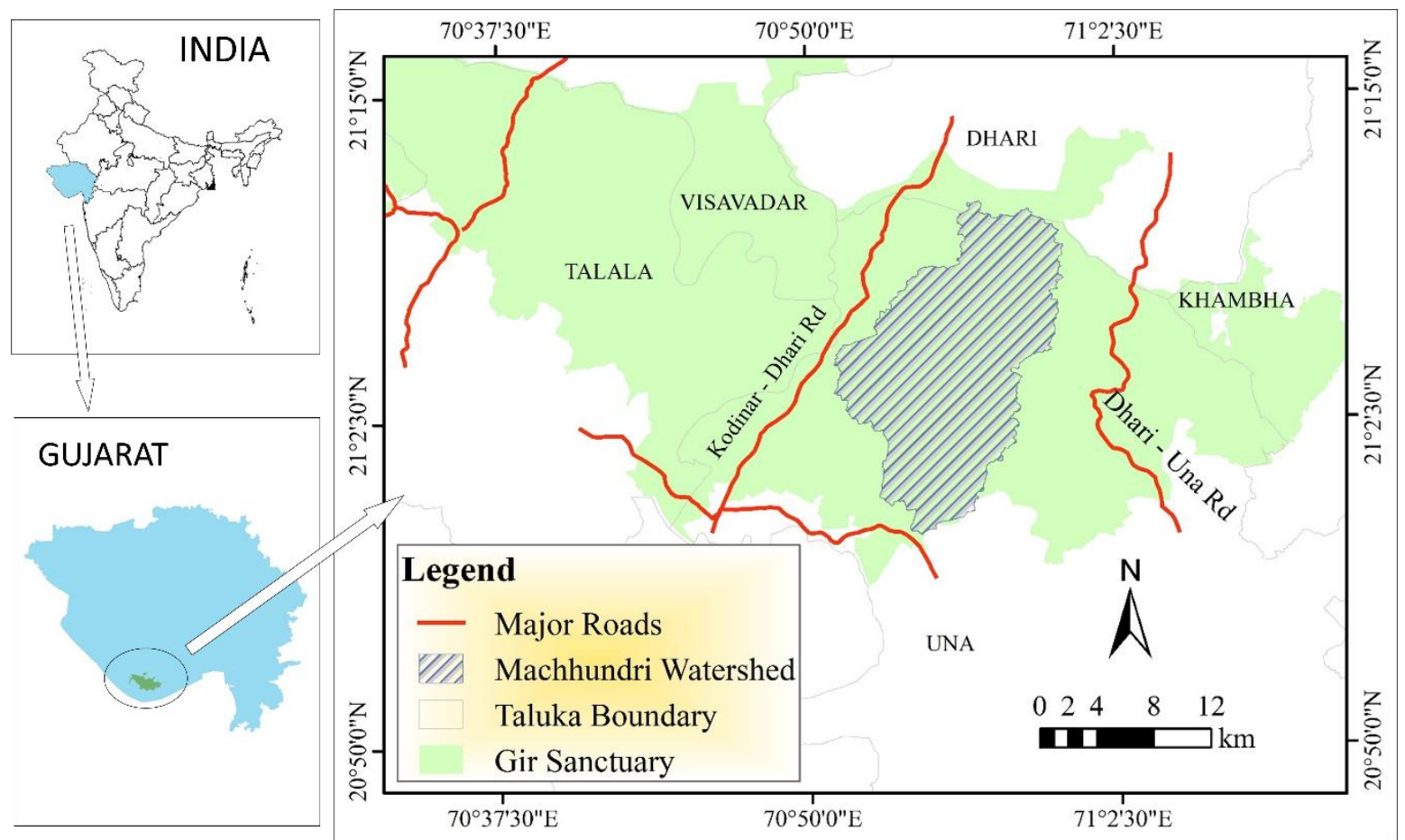
Fig.2 Contour, Aspect and Slope map generation flowchart

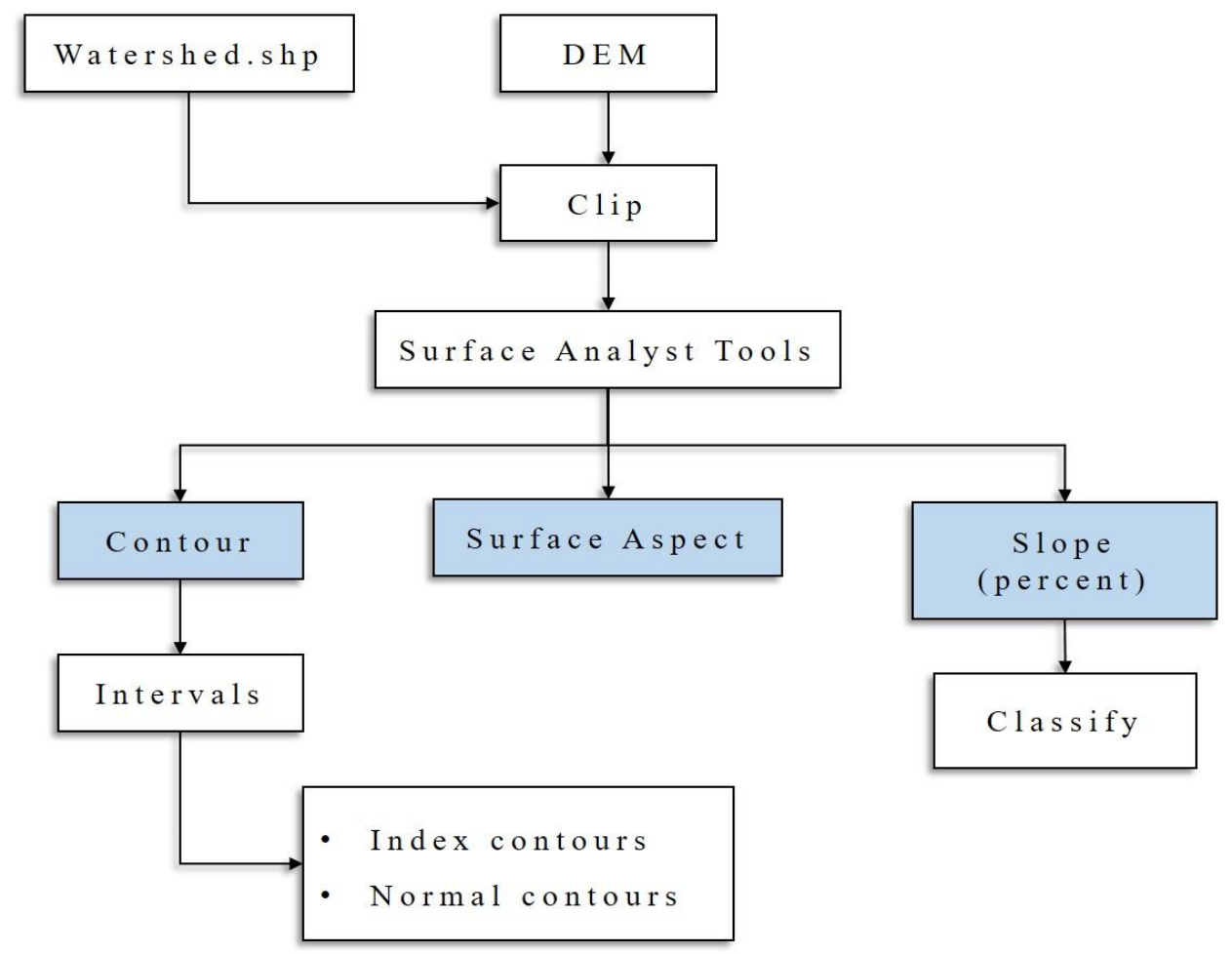

Fig.3 Drainage map generation flowchart

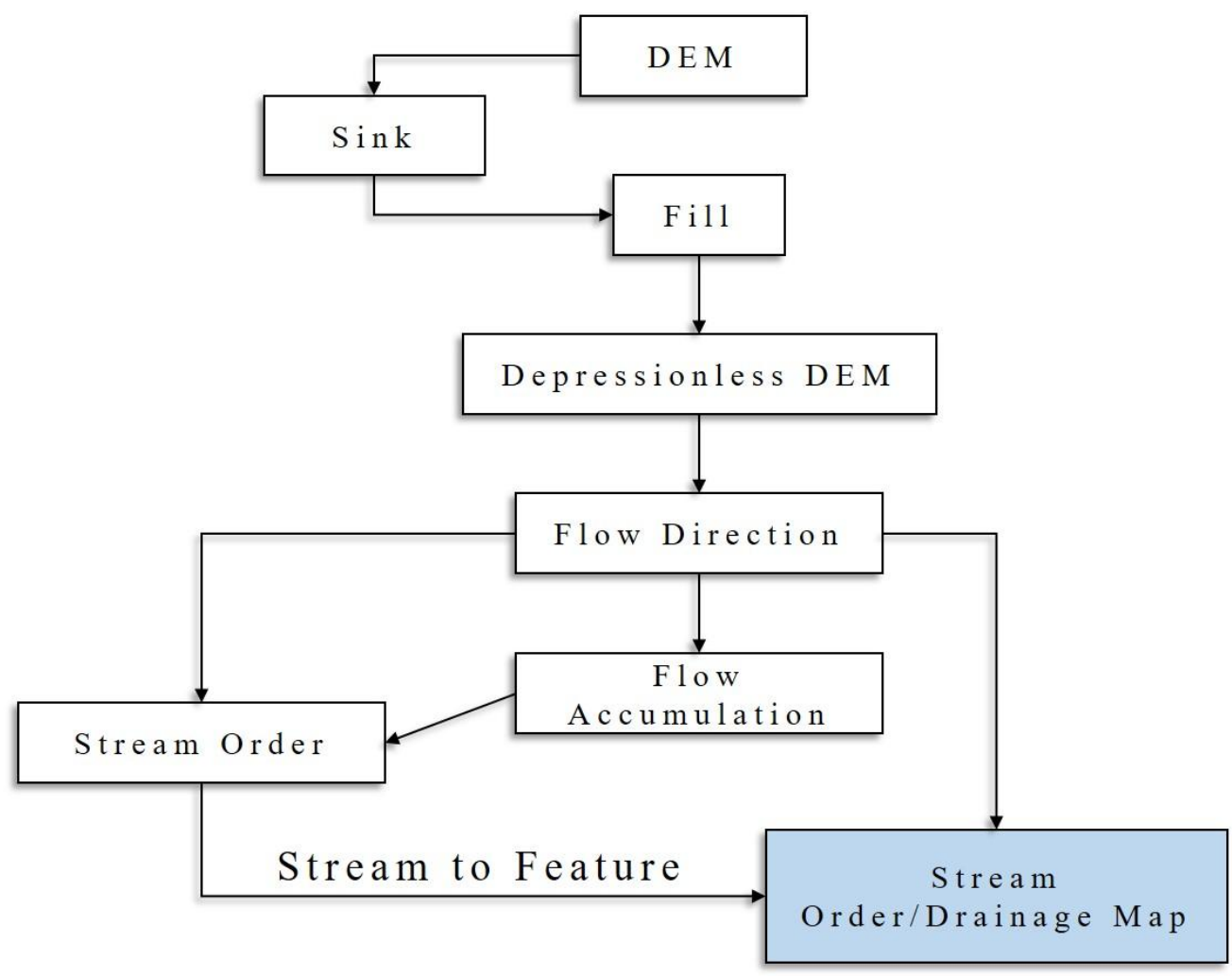


Fig.4 Digital Elevation Model of the study area

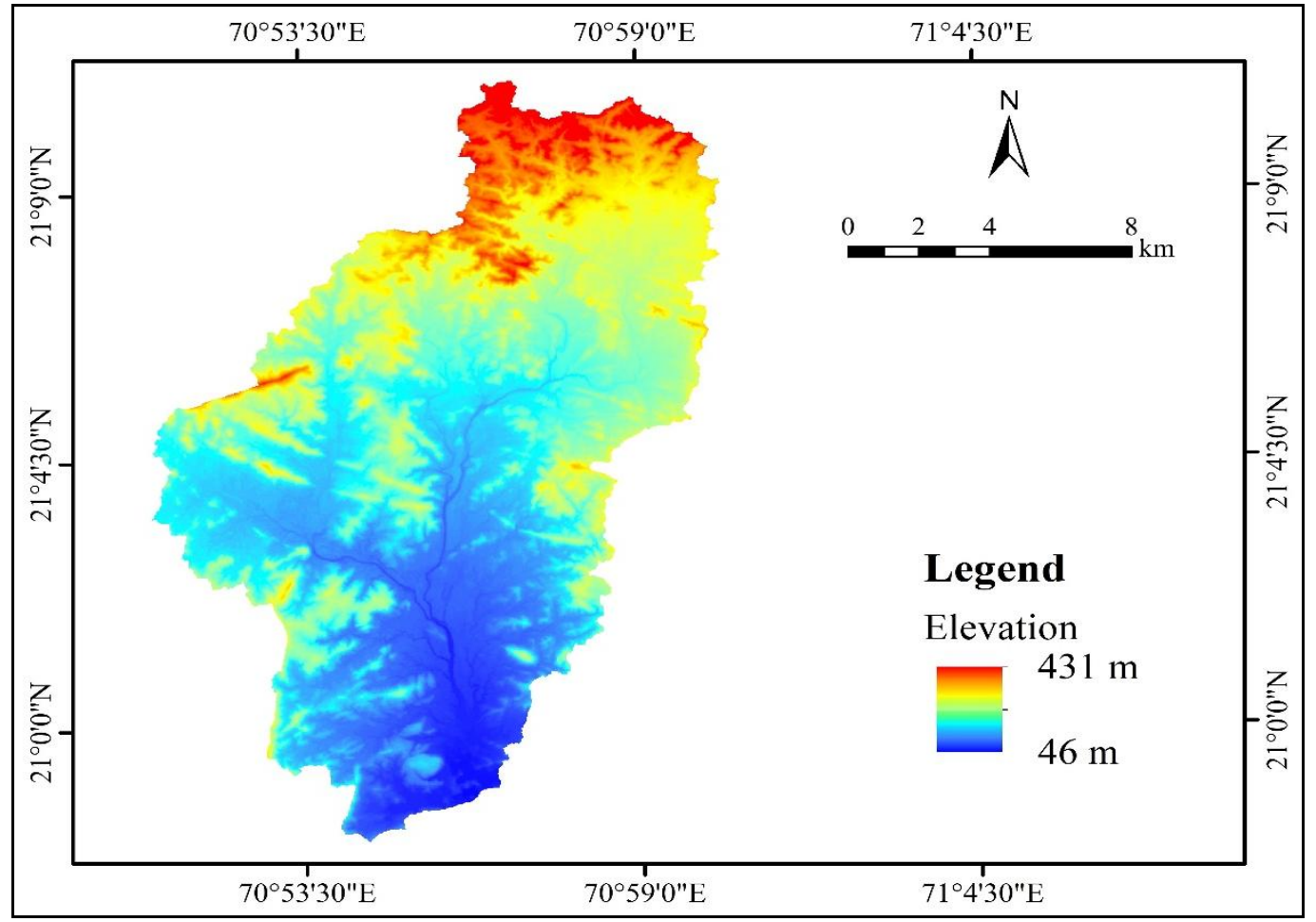

Fig.5 Slope map of the study area

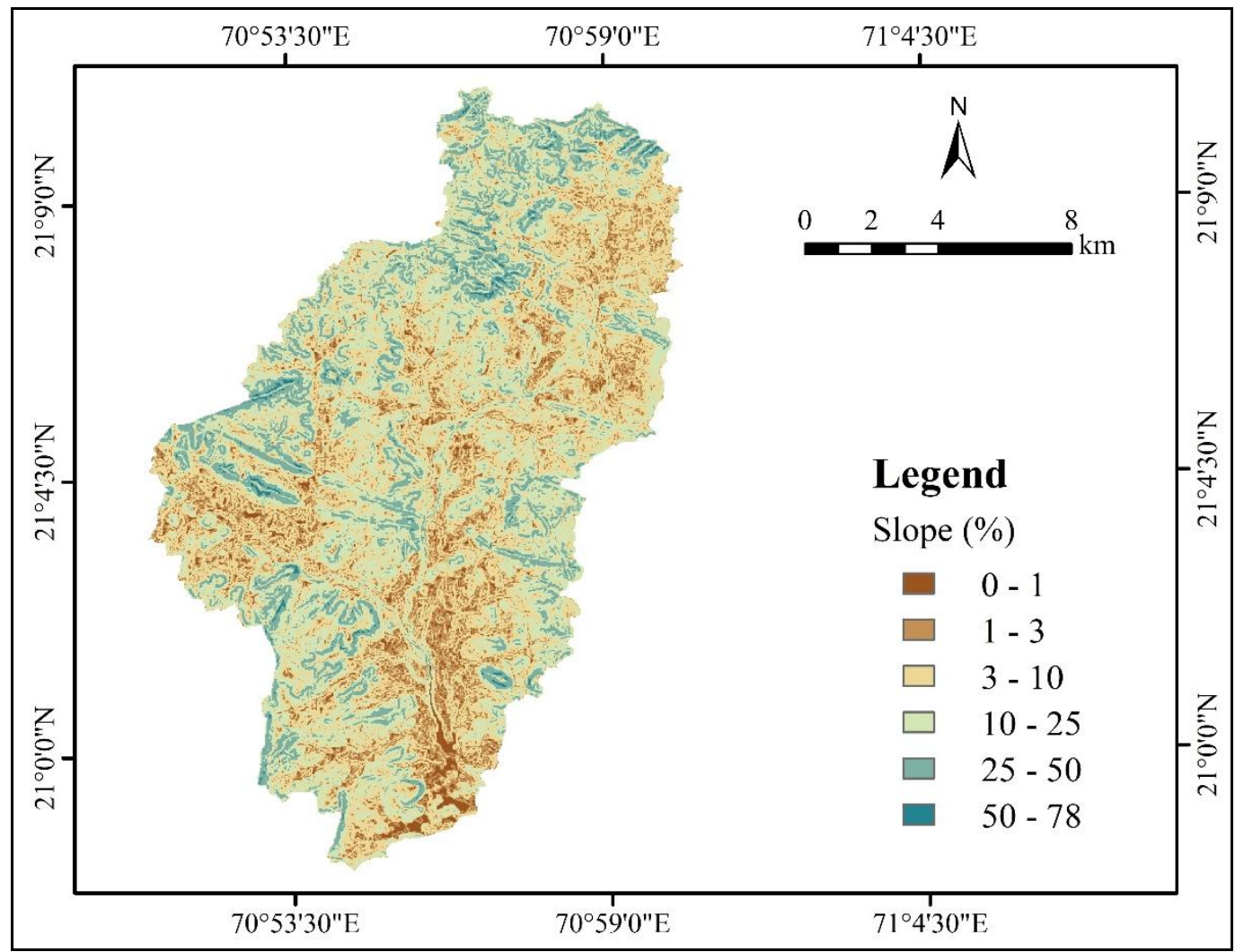


Fig.6 Aspect map of the study area

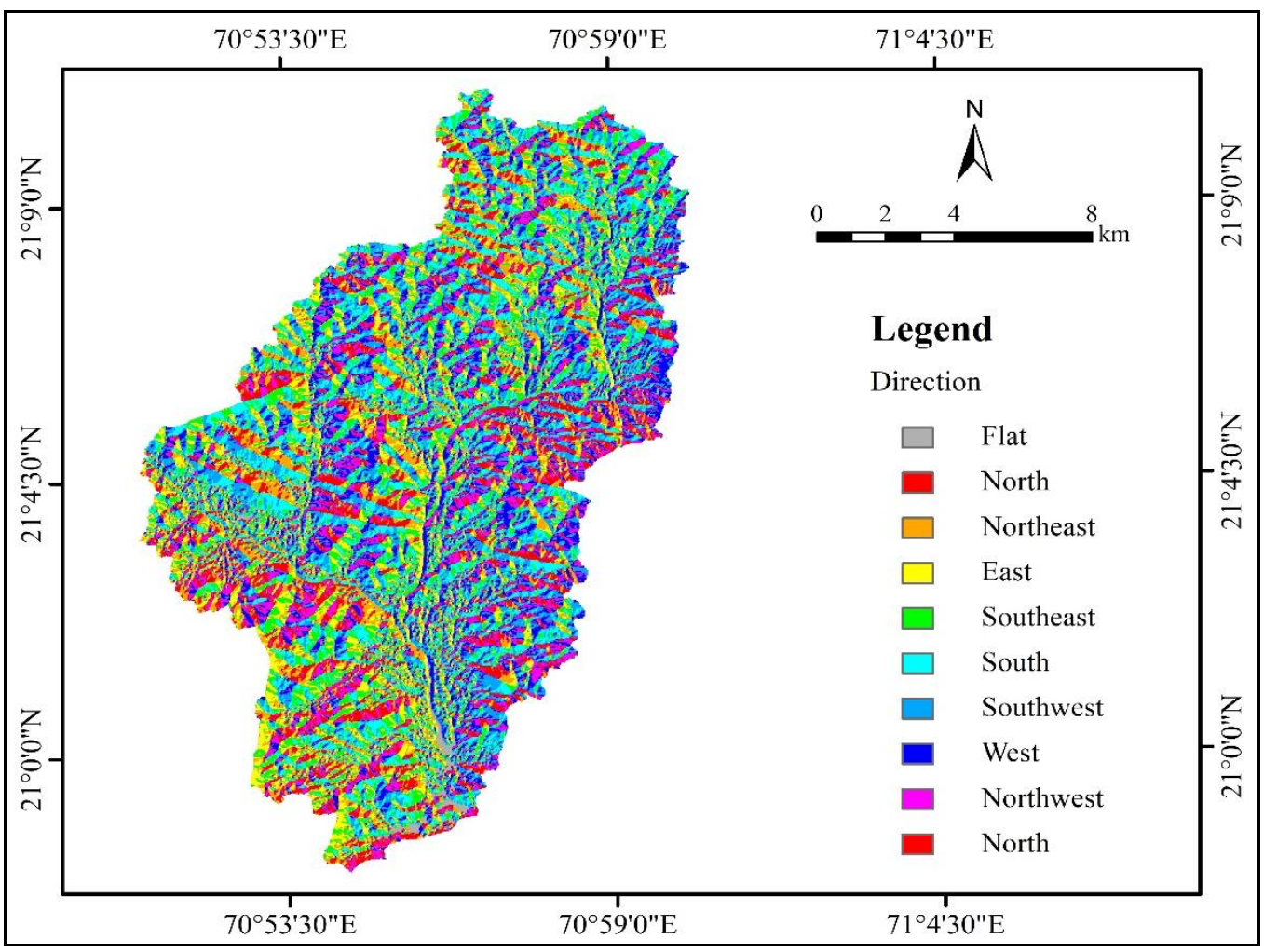

Fig.7 Contour map of the study area

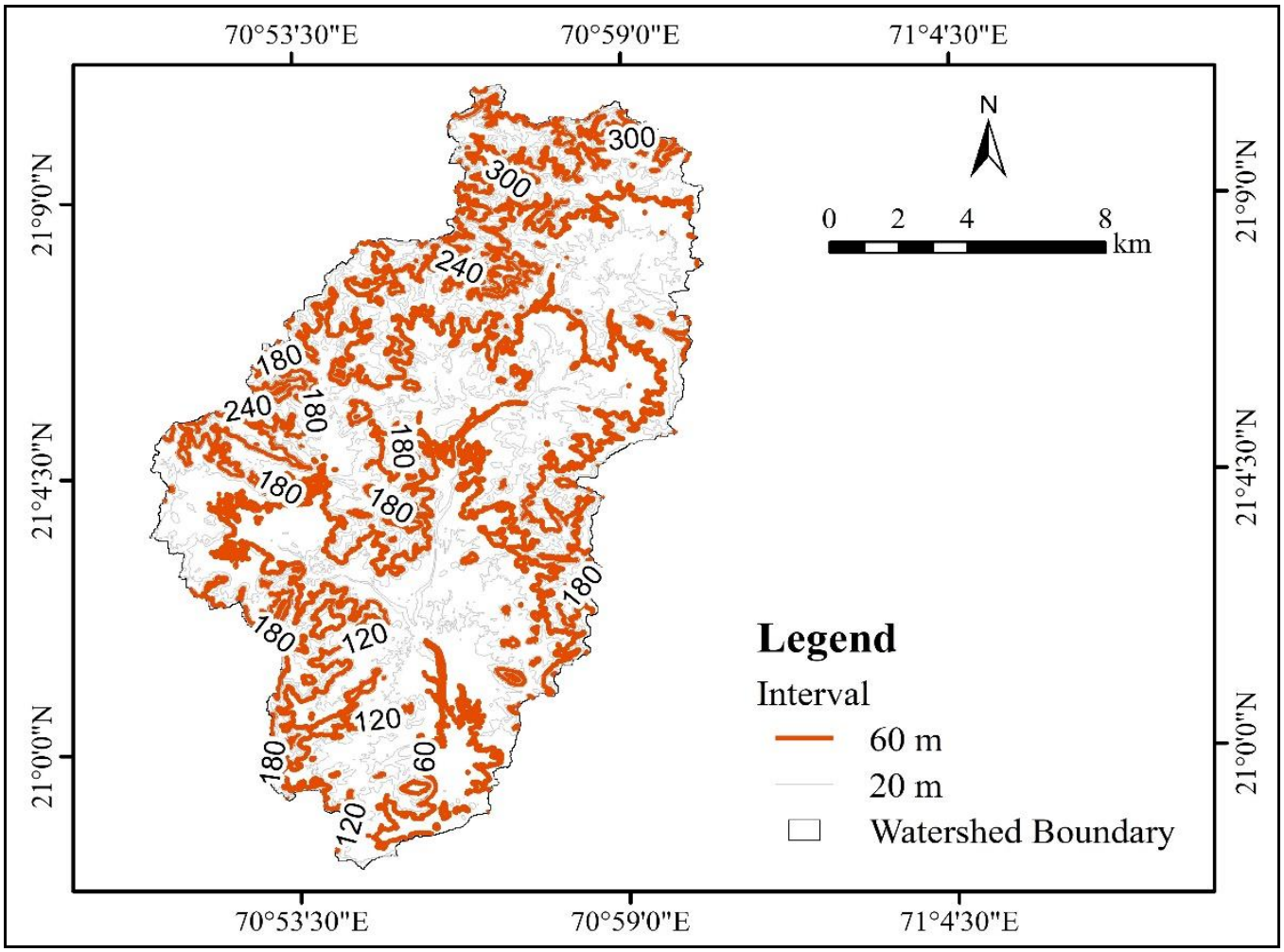


Fig.8 Land use/land cover map of the study area

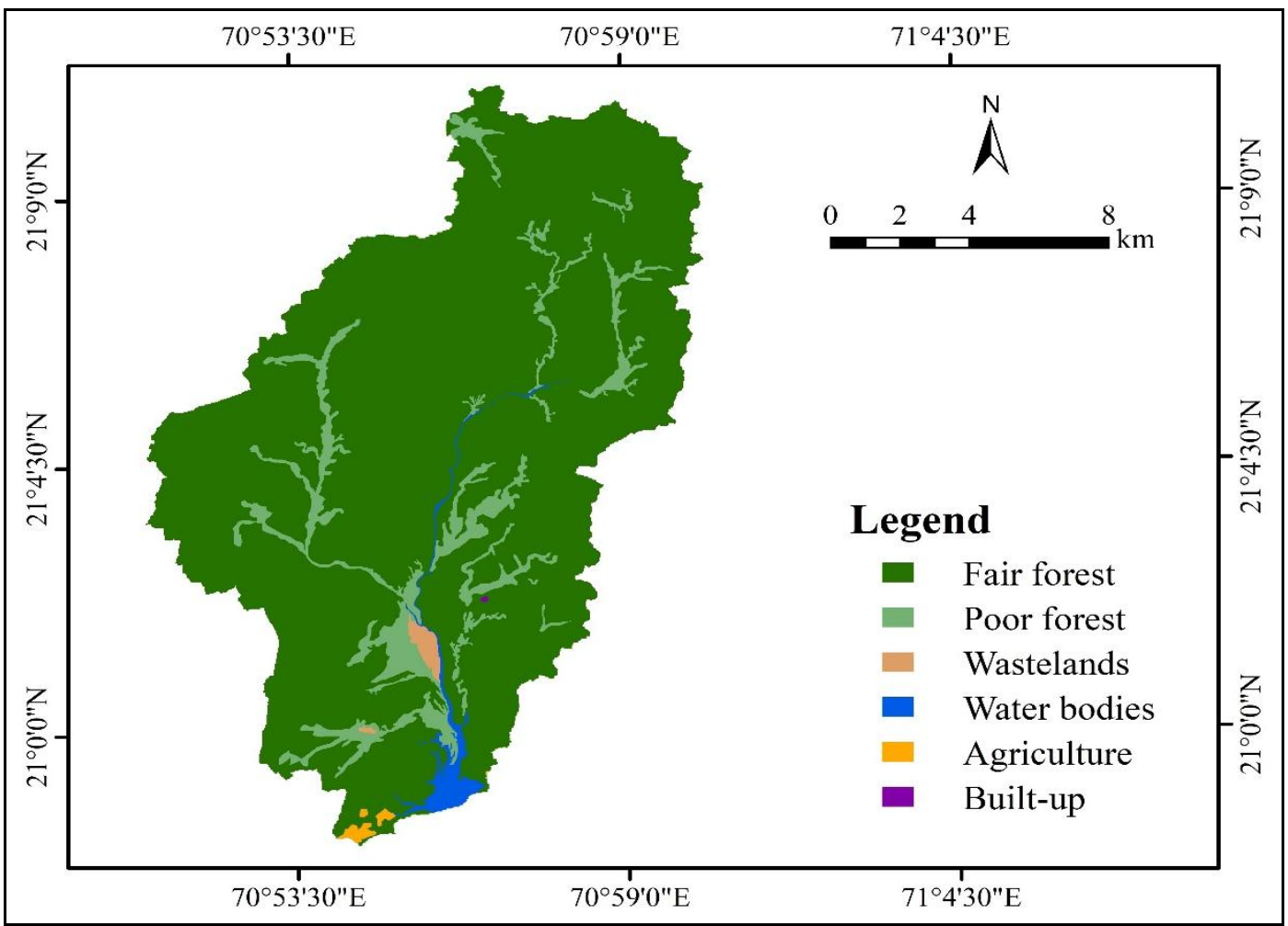

Fig.9 Soil map of the study area

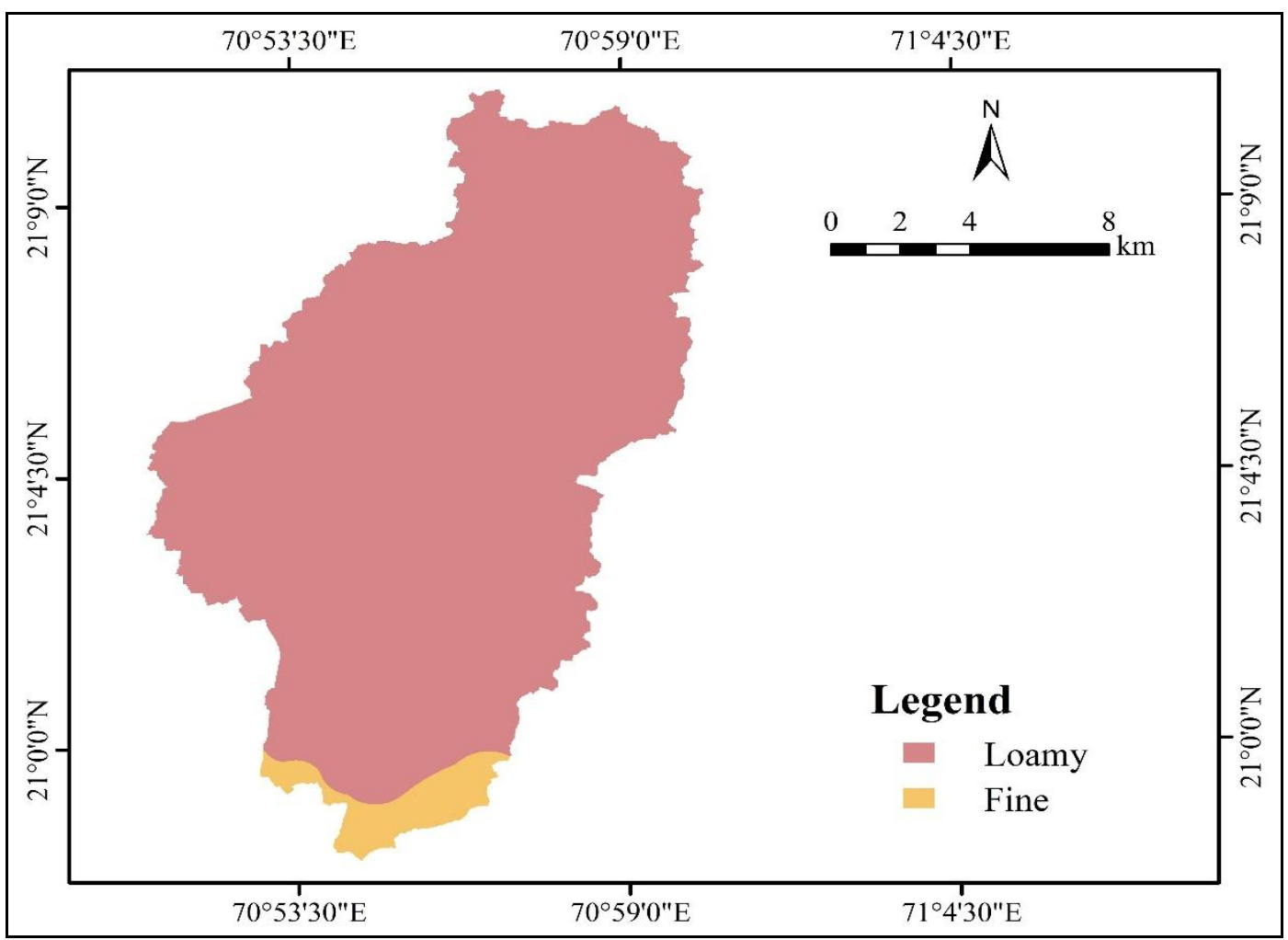


Fig.10 rainage map of the study area

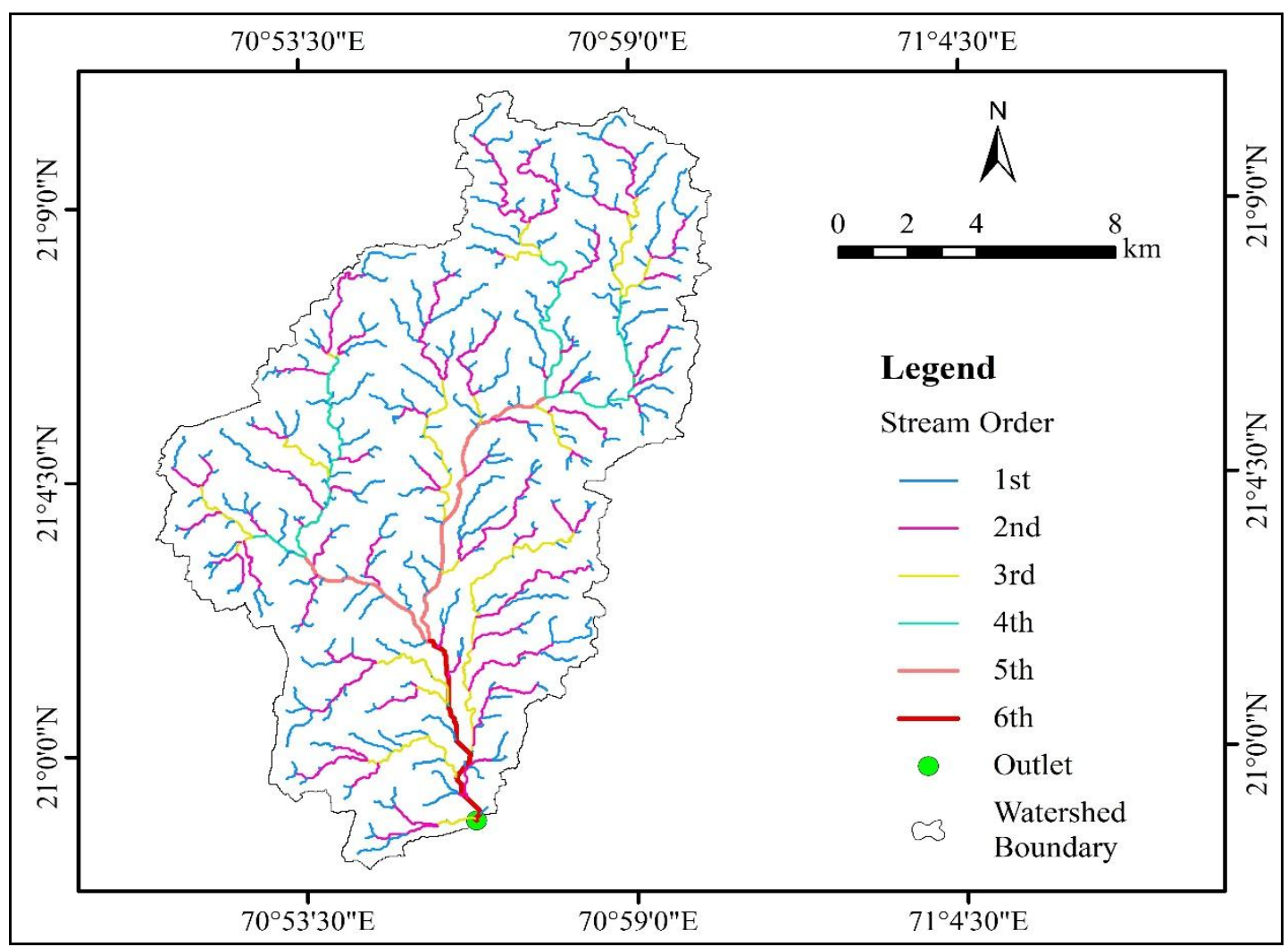

Dominant forest class in the watershed is the main explanation of low erosion in catchment. All land use/land cover classes with their area percent are presented in Table 2 .

\section{Soil map}

The soil types obtained for the study area were loamy and fine. The soil map is shown in Figure 9. Major percentage of watershed area (96 percent) is having loamy soil texture, whereas the downstream area of about 4 percent is fine textures soil. Loamy and fine soils are described as entisols, orthents, ustorthents, lithic ustorthents and inceptisols, ochrepts, ustochrepts, verticustochrepts as its order, sub-order, great-group and sub-group respectively. For loamy soil, taxonomy is described as loamy, mixed, hyperthermic and calcareous. While for fine soil, taxonomy is described as fine, mixed, hyperthermic and calcareous. Soil $\mathrm{pH}$ was tend to be slightly alkaline (7.5 to 8.5$)$ and moderately alkaline (8.5 to 9.5) for loamy and fine soils respectively. Soil depth and parent material were described as very shallow $(10 \mathrm{~cm}$ to 25 $\mathrm{cm})$ and basalt for loamy soil while moderately shallow $(50-75 \mathrm{~cm})$ and alluvium for fine soil, respectively. Soil area percent and description is shown in Table 3.

\section{Drainage map}

The study area watershed was having $6^{\text {th }}$ order basin as can be seen from drainage map generated. Total catchment area was 78.19 $\mathrm{km}^{2}$, perimeter of the basin was $64.04 \mathrm{~km}$ and maximum basin length of the study area was found to be $14.92 \mathrm{~km}$ respectively. Number of streams were decreasing as stream order was increased, which is clearly visible in Figure 10. Steeper slopes were mostly located near first order streams in the basin. 
Remote sensing and GIS can be precious techniques for developing thematic maps particularly in forest watersheds where access is limited. Most percentage of area (86 percent) of Machhundri watershed was found below $230 \mathrm{~m}$ MSL. Analyzing slope map, steeper slopes were found in upstream areas of the catchment. It was explored that the area is non disturbed as located inside a reserved forest, which may well be the reason of lesser erosion and low peaks of runoff. Almost no flat area was found from the aspect map which again corresponds to the undulated topography of the region. Denser contours were found in upstream side of the catchment while in downstream side, contours were moderately spaced because of relatively flat topography. Major percentage of watershed area (96 percent) was having loamy soil texture and almost 98 percent area is under forest cover. Watershed was found to be $6^{\text {th }}$ order catchment. These thematic maps will be valuable assets in many land and watershed management studies as fundamental inputs, since approach permit to the area is very limited.

\section{Acknowledgments}

We are sincerely thankful to Bhaskaracharya Institute for Space Applications and Geoinformatics (BISAG), Gandhinagar and Forest Department, Gujarat for providing required data to engage this study.

\section{References}

Kovarik, V. and Talhofer, V. 2013. General procedure of thematic map production using GIS technology. In: International Conference on Military Technologies Proceeding, ICMT, 13: 1401-1408.

Murthy, Y. V., Sinha, A. K., Jeyram, A., Srinivasa, R. S., Das, S. N., Pandit, D. S., Shrinivasan, D. S. and Rajender, C. K.2000. Integrated Watershed Developmental Planning Using Remote Sensing and GIS. In: Souvenir of workshop on Space Technology for Rural Development-NGOs Perspective. 18th April, 2000.

Paul, J. C., Mishra, J. N., Pradhan, P. L. and Sharma, S. D. 2008. Remote Sensing and GIS Aided Land and Water Management Plan Preparation of Watershed-A Case Study. Journal of Agricultural Engineering, 45(3): 27-33.

Peel, M. C., Finlayson, B. L. and McMahon, T. A. 2007. Updated world map of the Köppen-Geiger climate classification. Hydrology and Earth System Sciences Discussions, 4(2): 439473.

Srinivas, P., Sarala, C. and Chowdary, P. P. 2007. Integrated watershed management using remote sensing and GIS techniques. Nature Environment and Pollution Technology, 6(3): 463.

Suryawanshi, S. L. and Bhutada, S. H. 2010. Development of thematic maps for a watershed using remote sensing and geographic information system. International Journal of Agricultural Engineering, 3(1): 147-52.

Tejwani, K. G. 1976. Using and interpreting soil information for land capability, irrigability and range site classification. Soil conservation digest, 2(1), 47-52.

\section{How to cite this article:}

Gojiya, K.M., N.K. Gontia and Patel, K.C. 2018. Generation of Thematic Maps of a Forest Watershed using Remote Sensing and GIS. Int.J.Curr.Microbiol.App.Sci. 7(12): 2952-2962. doi: https://doi.org/10.20546/ijcmas.2018.712.337 